Article

\title{
From Protestant Peasant Dress to Gay Pride T-Shirt: Transformations in Sartorial Strategy Amongst the körtti Movement in Finland
}

\author{
Anna-Mari Almila \\ London College of Fashion, University of the Arts London, London W1G 0BJ, UK; a.almila@fashion.arts.ac.uk \\ Received: 4 April 2019; Accepted: 20 May 2019; Published: 29 May 2019

\begin{abstract}
This paper looks into the 200-year history of a particular Christian dress form in Finland, namely the körtti dress. Emerging from a declining peasant dress style, this supposedly unchanging and fossilised signifier of a revivalist Protestant movement has in fact gone through numerous transformations influenced by both socio-political and religious trends as well as fashion-driven and materially-ordained factors. From the analysis emerge four key factors that influence how dress strategies are formulated and enacted within a religious movement: (1) how vulnerable or institutionalised the movement is; (2) how it is viewed by those external to it; (3) how the members of the movement want themselves to preserve or change the movement and its public image; (4) and how external fashion processes infiltrate the tastes and sensibilities of the members. It is concluded that elements considered 'traditional', 'modern', 'secular' and 'religious' may all be present at the same time in a dress phenomenon, indicating that fashion's association with modern secularity is not as clear-cut as is sometimes thought.
\end{abstract}

Keywords: Protestant revivalism; Pietism; Finland; religious dress; dress strategy; symbolic boundaries; equal marriage

\section{Introduction}

Religion is often supposed to be associated with 'tradition' while fashion carries connotations to do with 'modernity'. This would seemingly place these two phenomena in different realms of life and render the interfacing of fashion and religion an oxymoron. Yet we know this is not the case. Both everyday realities and research literature show time and again that fashion and religion form alliances: there are religion-focussed fashion industries, religious fashions and fashionable religiosities (e.g., Lewis 2015; Tarlo and Moors 2013). Dress has been central to many religious movements, groups and sects throughout history (Arthur 1999, 2000; Barker 2001; Hyme 2013), including Christian churches, movements and sects (Classen 2004; Hawley 2017). Contrary to popular beliefs, fashion and religion are not automatically and essentially opposed or contradictory concepts, although they may so become, depending on social conditions. To throw light on operations of these realms when brought together, I explore how they have played alongside or against each other in one specific case. This is the case of Christian körtti dress in Finland from the early 19th century onwards. Körttiläisyys is an awakening movement that operates within the Evangelical Lutheran Church of Finland, which is Finland's state church. Their traditional dress has been considered 'the most noticeable [religious] orientation dress' within Finnish Christianity (Vilkuna 1928, p. 61, my translation). I will argue that the dress in question is in fact much more. When subjected to sociological analysis, the history of the dress can be used to reflect upon wider historical changes and tendencies.

To speak to the interfaces of fashion and religion, I must start with a consideration as to what I mean by both fashion and religion in the frame of this paper. As regards fashion, there are a number 
of fashion processes involved here. While there have been changes in taste for certain styles and garments in wider Finnish society for a long time, these have also been enabled by the production, distribution and retail of goods (Kopisto and Sihvo 1996). Such fashions may penetrate religious garment systems both by the desire of wearers and for pragmatic reasons. The fashionability and availability of one thing can affect the desirability and accessibility of other goods. For example, an increase in availability of factory-made textile materials is likely to reduce domestic spinning and weaving activities, altering common dress materials and styles. The appearance of certain kinds of buttons in a local shop may mean that the 'old-fashioned' type is no longer available. I show how such elements of fashionability can penetrate even the most strictly protected dress styles, introducing subtle change in supposedly unchanging dress. Fashion is not only a wider process of change (Aspers and Godart 2013); it is also a system through which numerous minor changes are offered to or forced upon the wearers of clothes. I explore 'fashion' in this paper recognising the multiplicity and variation of the phenomenon. In so doing, I seek to contribute to fashion scholarship involved in explorations of fashion in times, locations and realms usually not associated with it, thus challenging normative and hegemonic understandings of the concept (Almila and Inglis 2017).

I also recognise that 'religion' is not an unchanging, internally coherent concept, but is indeed lived and expressed in manifold ways (Dillon 2003; Jensen 2014). In spirit of Max Weber, I look into the 200-year history of a specific societal order, seeking to comprehend what kinds of lessons it can teach us about the interconnectedness of the realms of the religious and the fashionable. An important question in terms of religion is to which degree the körtti movement has, in different phases of its history, been more sect-like or sectarian, or more movement-like and openly defined. This, I argue, has directly influenced various dress strategies within the movement. According to Weber (2002), Protestant sects have historically strictly controlled both entry into a sect's membership and members' behaviour after affiliation. We will see that the latter was certainly true of the körtti movement in its most 'sectarian' phase. In this regard, heightened dress control seems a good indicator of a high level of seclusion of a religious group, as well as a sense of external threat within a religious movement. Dress's role in such a situation is to build and enforce strong symbolic boundaries for the sake of protection (Douglas 1984). Conversely, we will see that today, when the körtti movement is well established and integrated within the Church, dress operates in a much subtler manner. Dress is still used to make statements and to indicate and create belonging, but the boundaries formulated are weak and the strategy often is to seek to cross boundaries rather than to erect barriers.

Finally, I show how no group or movement can control their dress from inside the group only. Others will 'read' their dress, form their interpretations, and react accordingly. Therefore, a spontaneously donned, religiously defined attire can irritate an established religious leadership to the extent that they prefer fashionable clothes-which Christian churches often have shunned and condemned (Ribeiro 2003) —instead. Under different historical conditions, the same style of dress may come to be politically charged as well as religiously appropriate. I show, therefore, that as societal conditions change, so too change the meanings associated with an otherwise relatively stable style of dress. At the same time, numerous fashion processes make even the seemingly fossilised dress transform in more or less subtle ways, and such changes may indeed be deemed necessary, in order to keep the dress style alive. Importantly, there are various strategies involved in these processes whereby individuals and groups seek to ensure their own survival and to influence others at the same time.

\section{Context and Methods of Research}

To help the reader situate the argument presented in this paper, some contextualising is necessary. The narrative starts in the early 19th century, when Finland had been conquered by Russia and became an autonomous part of the Empire in 1809. The Evangelical Lutheran Church had previously been part of the Church of Sweden, and now came to be a separate State Church with the (Orthodox Christian) Tsar of Russia as its head. The clergy of the time belonged to a higher estate of social standing, along with the gentry and, increasingly, the bourgeoisie. The estate of independent peasants, as well as those 
of no estate, were of a lower social standing, and this distinction was strongly marked by dress and textile materials: 'the nebulous border between frieze jacket and broadcloth coat' marked the boundary between higher and lower estates (Topelius [c. 1870s] in Kopisto and Sihvo 1996, p. 25).

Throughout the 19th century, Finland remained largely rural with limited ongoing urbanisation processes. The central locus of social and political life was typically the church, which was also a channel of information spreading: official and other announcements were publicly declared by clergymen after each weekly service (kuuluttaa kirkossa-to proclaim in the church). Körtit were typically independent peasants, and their gatherings happened in private houses. Körtti preachers were known to travel unusually frequently (mostly on foot), and this practice enabled the movement to spread and form connections across the country. But it also caused authorities to view the movement with suspicion, as it was not considered desirable that the peasantry moves around and gathers together in its own terms (Huhta 2007).

Already in the earlier 17th century, it was known that 'God does not prohibit moderate and respectable apparel according to estate and occupation, but if someone clothes themselves above their rank and estate, this God cannot suffer' (Sorolainen [1625] in Kopisto and Sihvo 1996, p. 24, my translation). During the 18th century, the Swedish state had sought to regulate imports (as well as uphold the estate system) through sumptuary laws that allowed exported finer fabrics and jewellery only for the use of the higher estates. The sumptuary distinction between estates was revoked in 1794, and sea trade de-regulated. However, the change in peasant dress was initially slow due to reasons of custom and economy. In the mid-19th century, rapid economic growth and increasing industrialisation made ready-made textiles and garments more accessible for the lower estates, and the de-regulation of land trade in 1859 opened new fashion opportunities for rural lower-estate people. Home-weaving and home-sewing became less common (Kopisto and Sihvo 1996).

Urbanisation in Finland increased towards the end of the 19th century, and this enabled the körtti movement to spread to Helsinki and other cities (Salomäki 1978). Although urbanisation continued before and after Finland's independence in 1917, the most significant wave of it only happened after WWII. This led to the urbanisation of the körtti movement itself, whereas previously it had been a characteristically rural movement, its urban branches largely run by students from the countryside. Particularly from the 1960s onwards, the körtti movement has undergone a process of value liberalisation, first initiated by young left-wing clerics who sought to challenge the movement's previous right-wing association. The central argument was that Christians and the Church should not turn their back to the world but should instead seek to be a positive force in society (Salomäki 2010).

In my analysis, I draw upon various kinds of sources. The first empirical section is based upon archival and museum sources, namely written and image sources held by the Finnish Heritage Agency (https://www.museovirasto.fi/) and the University of Helsinki. I have also drawn upon written and image sources, as well as preserved garments, in the collection of the Körtti Museum in the town of Lapua (https://www.wanhakarhunmaki.fi/korttimuseo/). The data is somewhat scattered, yet the bringing together of writings about the körtti dress, photographs and other images, and actual surviving garments, has enabled me to construct a narrative of how the dress itself and ideas about it have transformed over time, both inside the movement and outside of it. An additional source has been my extended family's family albums.

For the second empirical section I have gathered data through interviews and also more informal conversations. My key informants were five people (three women, two men) who had been actively participating in creating new kinds of garments for the purposes of the movement. Some of these people work for the movement's central association, Herättää-Yhdistys, or for the Church itself, while some also volunteer for the movement. Through them I was able to learn all sorts of motivations behind the garments, which helped me to situate these in the wider politics within the Church and beyond. I have also gathered information using online sources, as the körtti movement and many of its members today often operate in virtual environments. The platforms used involve Instagram, where the hashtags \#körtti and \#körttipuku gave some useful results, and Facebook, where similar 
searches revealed groups set up for volunteers to hand-make garments for the benefit of the movement. In addition, I conducted searches in the main online discussion forum of the movement, Körttifoorumi (foorumi.h-y.fi).

\section{What Is körtti?}

Körtti (pl. körtit) is a member of a specific Christian religious movement within the Evangelical Lutheran Church of Finland. Körttiläisyys is a Protestant revivalist movement, which emerged amongst Finnish peasantry in the late 18th and early 19th century (Salomäki 2010). It was influenced by the ascetic Pietism of the 18th century, which took different forms across Europe. In its strictest form, Pietists formed sects of believers, who through physical separation from wider society and 'also in the visible aspects of their daily lives ... sought to remain certain of their own elect status' (Weber 2002, p. 81, emphasis mine). The movement is also known as Herättäjäliike or herännäisyys (the Awakening Movement, awakening), and the central association that manages the movement's activities is Herättäjä-Yhdistys (the Awakening Association, founded in 1945). The name initially indicated that members of the movement had 'awakened' (herännyt, pl. heränneet), unlike those who lived their life in a sinful dream without a proper sense of the sorrows of the world (suruton, pl. suruttomat, the sorrowless). A central theological position of the movement is that a human is salvaged solely through mercy (Salomäki 2010), and many of the members today do not consider themselves as 'believers' (uskovainen, pl. uskovaiset) but 'hopefuls' (toivovainen, pl. toivovaiset) in terms of their religious reliance and practice. They think that the custom of many revivalist movements to stress active individual faith is in contradiction with the idea that only God is great, and only God can deliver salvation, which a Christian can only hope for.

These characteristics of a Moravian Pietist sect in 18th-century Germany carry clear similarities to early forms of Pietism in Finland:

(1) ... religion was pietistic, stressing [the practice of piety in daily life] and ethical conduct over and above doctrinal uniqueness; (2) it was Christocentric, regarding Christ as the sole vehicle through which man could hope to comprehend the nature of the divine, and worshipping him as the Saviour whose sufferings on the Cross had atoned for sins; (3) it was emotional. Belief was matter of feeling the divine, not of understanding it. The heart, not the mind, was thought to be the seat of religious experience. ... (4) It was social, defining religion as group experience in which the faithful were bound together in community of love, but at the same time separated from the rest of mankind who did not share their beliefs and who therefore were not to be numbered amongst chosen people. (Lindt-Gollin 1967, p. 92, emphasis in original)

Early Pietism in Finland had many ecstatic elements, which came to be considered undesirable towards the late 19th century and especially in the early years of the 20th century and were thus excluded from the movement (Huhta 2007). While a sense of community belonging is still a central part of the movement today, the idea of separation came to be viewed negatively after the wars and particularly when the movement liberalised from the 1960s and 1970s onwards. Therefore, although some of the members of the movement still use the word Pietism to describe their movement (and, for example, the Körtti Museum uses the word in translations), others reject the word as it does not describe well the current state of the movement. Körttiläisyys today is not a sect but a fairly freely organised movement with relatively loose theological interpretations (Salomäki 2010). Although there is a central association managing the movement, the movement itself is not organised in a centralised manner. Some körtit say that the only thing that truly binds the movement together and is recognised by all the members of the movement is their hymn book, Siionin Virret (the Hymns of Zion). 
The origin of the word 'körtti' is unclear. The most common reading is that the word refers to a specific and highly recognisable detail of the körtti dress (körttipuku), which appears in both the male and (in a less striking form) female dress: several slits or pleats at the back of the jacket (today, 3 slits in a male jacket [västi, röijy], 3 short pleats in a female jacket [röijy]), which form loose-hanging 'skirts' (particularly prominent in the male jacket, Figure 1). The word is supposed to derive from the Swedish word 'skört', meaning the skirt of a coat or jacket. This dress detail is still central to the style of körtti dress today and is known as körtit ( $\mathrm{pl}$. for körtti). An alternative explanation for the word refers to a geographical location where körttiläisyys emerged powerfully in its early years: Keyrettijärvi (lake Keyretti). According to this explanation, these people would have been referred to as keyrettiläiset (of Keyretti), and this word would have then been corrupted into körttiläiset (Vilkuna 1928). Both explanations stress that the name was initially a derogative expression but has for a long time now been embraced by the members of the movement. Historically, körttiläisyys has been associated with the Savonia area in eastern Finland and the Ostrobothnia area in western Finland. It spread from these areas to North Karelia and Kainuu in eastern Finland. Today, the movement is spread practically everywhere in Finland.



Figure 1. The male körtti dress with distinctive 'skirts', 'körtit'. Photograph: Wilhelmi Malmivaara (1854-1922) in Heränneen kansan arkea ja pyhää, 1952.

The garments of körtti dress were traditionally made of home-grown wool, linen and hemp, but in its later versions, half-woollen blend fabrics, cotton and occasionally even synthetic materials have been used. The colour has been primarily dark: grey, blue or black, the use of black becoming more standardised with time (whereas in the early 20th century, for example, the male summer dress was sometimes made of a light grey material-Vilkuna 1928). The male attire includes a jacket with a stand-up collar and the distinctive slits in the back, trousers of the same material, and a hat. The female attire is formed of a short jacket with short pleats or slits in the back, a wide skirt pleated on the waist, a blue-striped (previously often also checked) scarf over the shoulders and across the breast, and a dark scarf on the head. Hair was traditionally parted in the middle (Figure 2). 


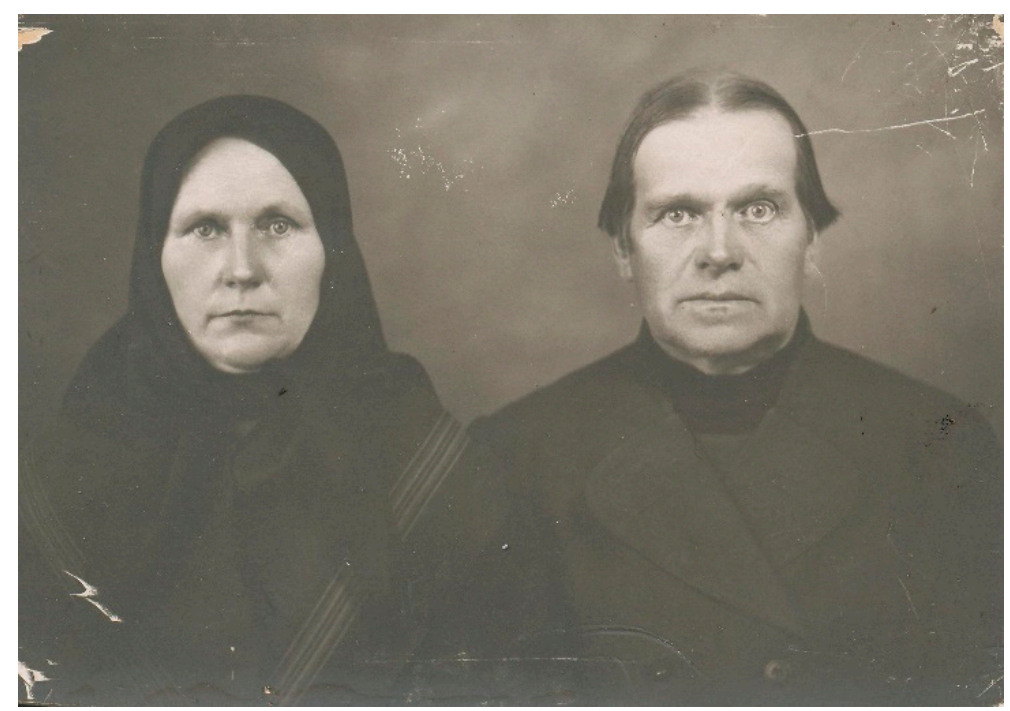

Figure 2. Author's great-grandparents in körtti dress, c. 1920s/1930s. Photograph: family album.

Körttiläisyys today is one of the established revivalist movements within the Evangelical Lutheran Church of Finland - there are altogether five such movements in existence. It is also the most liberal of the movements, both in terms of its membership's values and its leaders' statements (Salomäki 2010). People associated with körttiläisyys, or those who consider themselves to be a körtti, are not necessarily formally members of the movement. For example, in 2017, members of Herättäjä-Yhdistys counted at 5196, while the annual summer festival of the movement, Herättäjäjuhlat, attracted an estimated audience of 21,000 (Herättäjä-Yhdistys 2018).

The körtti movement has gone through a number of phases and transformations during its 200-year existence. These can be loosely summarised as follows: (1) the time of emergence and sectarianism; (2) the time of dispersion; (3) the time of integration and nationalism; (4) the time of organisation; (5) the time of liberalisation; and (6) the time of the Church in crisis. Each of these eras has demonstrated specific dress and fashion characteristics, which I will outline in what follows.

\section{A History of the körtti Dress: The Rise, Struggle and Decline of a Conservative Peasant Dress}

Tracing the history of the körtti dress is somewhat challenging, as reliable documentation of the dress, its geographical locations and exact time of emergence is limited. The Körtti Museum at Lapua has a collection of körtti garments, but they have limited information as to the background, history and details of each garment. However, their collection is testament to the fact that, unlike the general assumption that körtti dress is an unchanged, traditional dress style, there have actually been numerous changes and differences in style, material, colour and detail across Finland and locally, too. I seek to trace some of these changes and their context here. I am not aiming to give a detailed description as to how the dress has spread and transformed through time, but to stress the fact that both the dress and meanings associated with it have gone through many changes. From these changes we can learn something about the symbolic boundaries and types of recognition and affiliation necessary for religious groups and movements in certain points of their existence.

\subsection{The Time of Emergence and Sectarianism}

Most sources seem to place the emergence of the dress style as associated with Pietism in the 1820s/1830s, when Finnish Pietism was powerfully influenced by Paavo Ruotsalainen (1777-1852), a farmer who became a lay preacher and one of the key characters of the early Awakening movement. The male körtti dress of the time seems to have been a form of rural dress that had already gone out of fashion in western Finland and was also declining as a style in the eastern Finnish Savonia area where Ruotsalainen came from (Figure 3). 


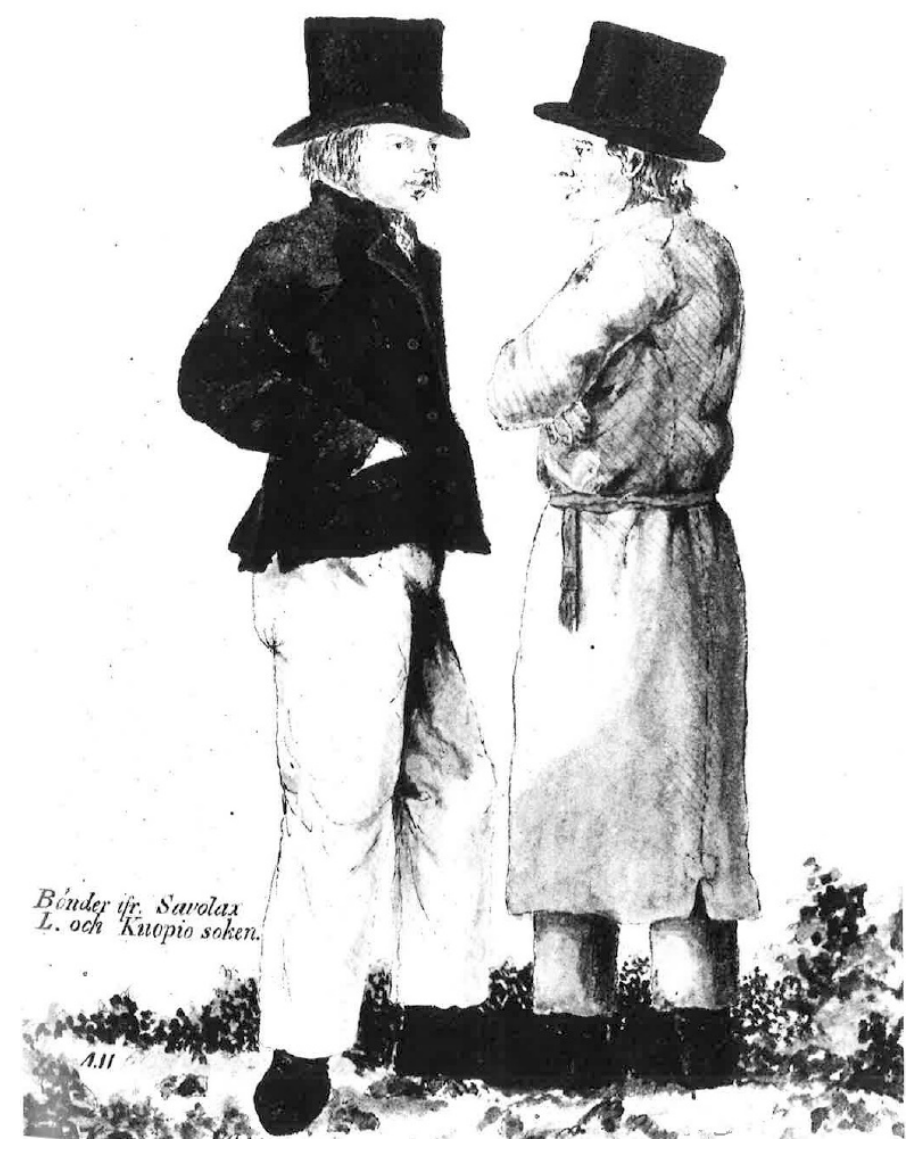

Figure 3. Peasant dress in Savonia in the 1820s. The man on the left wears a jacket much like the körtti jacket. Watercolour by Adolf Hårdh (1807-1855).

One interesting element of the körtti dress is that it was not recommended, let alone enforced, by the leaders of the movement. Although Ruotsalainen and other spiritual leaders preached against vanity and 'showing off' (koreilu) and condemned certain styles and colours (especially red and multicoloured garments were considered sinful), there was no direct incentive to make people dress in any particular manner (Vilkuna 1928). The dress style seems to have been donned fairly spontaneously, and it spread when members of the movement visited each other in different parts of Finland. At this time, there were ecstatic elements in the movement, and 'awakening' often happened as a radical transformation, which came to involve the changing of one's clothes (Mäntykoski 1973). This sometimes involved dying one's clothes black, or giving away or even burning old, now undesirable garments (Hakulinen 2008). Instead of throwing old clothes away and making new ones, an awakened individual could also indicate their awakening by attaching long 'skirts' to the hem of their jacket (Vilkuna 1928). The early leaders of the movement eventually came to consider this transformation as positive, as is shown in the statement of Jonas Lagus (1798-1857), an Ostrobothnian (north-west Finland) körtti preacher:

What, then, is the profit of change? First, that [the awakened] in one go are liberated from worldliness, and then, that they publicly part with their previous company, and finally, that they take up dress suitable for them. (in Vilkuna 1928, p. 66, my translation)

The dress came to be a symbol and visible indicator of religious and spiritual transformation, and as such it also created symbolic boundaries, marking a difference between the 'awakened' and others. Such a distinction seems to have been particularly desirable as it underlined the separation between groups: an awakened körtti could not keep the company he or she kept before. It was necessary for the establishment of the movement to ensure that those who joined it would stick to it. What better means than making the boundaries visible and embodied? 
It is perhaps also understandable that the colour red was particularly horrendous to these preachers. Legends tell that Paavo Ruotsalainen would powerfully reproach peasants with red belts, and considered multicoloured women's clothes 'Lucifer's robes' (Vilkuna 1928, p. 65). The colour red spread along with fashionable dress among the Finnish peasantry during the 19th century, as sumptuary laws had been overturned, colour regulations removed, sea trade deregulated, and the wealth of independent peasants increased (Kopisto and Sihvo 1996; Lehtinen and Sihvo 1984). It was from this estate that the members of the körtti movement sprang, and therefore it was the dress popular among their worldly peers from which they needed to make a distinction.

The movement did not please all clergy or state officials. It was considered highly suspicious that peasants independently gathered together and created and preached religious interpretations outside the power of the Church. Russian officials did not consider it desirable that people moved around the country causing divisions, forming alliances and sharing opinions in an uncontrolled manner (Huhta 2007). In the 1840s, a number of leaders and members of the movement were summoned to court to answer charges against their religious practices, including their chosen dress style. A response to such charges is illuminating:

We have put away silk and other expensive dress, which is unsuitable for the peasant estate, and have taken on such attire, which has historically been usual in the land, and which is still [worn by] our parents, and almost commonly [by] Savonia, Häme and Karelia [eastern and central Finland] inhabitants, who still have kept their craft, and have not, in madness for clothes, so deplorably spoiled their simplicity as the inhabitants of this [western] coastal land. (Independent peasant Matti Niemi, in Vilkuna 1928, pp. 63-64, my translation)

Influenced by sea trade, fashions at that time tended to spread from the west coast towards inland (Kopisto and Sihvo 1996), and Vilkuna (1928) has indeed argued that the körtti dress typically emerged in more rural, out-of-the-way places where fashion had less influence. So, in essence, the dress was a rural, conservative anti-fashion form of attire. Interestingly, the Church found this highly suspicious. Clergymen argued that wearing such ugly garments was not religiously appropriate (Huhta 2007). The grassroots character of the movement threatened Church power, and had the potential to cause unrest within it, while fashionable garments kept people peaceful and contented. In the frame of standard narratives of religious leaders and movements being hostile to fashion, the case of körtti dress shows that the opposite can be true when fashion is deemed to serve purposes of religious (and political) stability.

Here, Vilkuna (1928) claim about how the körtti dress spread is particularly interesting. According to him, it avoided places with churches (kirkonkylä, literally 'church village', a centre of social and governmental activities). The dress was therefore particularly striking when the körtti peasants arrived in church on Sundays. It was a visible challenge from peasantry to the Church, from the periphery to the centre, albeit its wearers not necessarily considering it as such (Huhta 2007). Just like the Pietist movement was highly suspicious for the European Calvinists and Lutherans (Weber 2002), the Finnish körtti peasant was problematic for the authority of the clergy, the Church and the State. Part of the reason for this was probably that the asceticism and centrality of emotions that were so crucial for the körtti movement in its early days are 'foreign elements' for Lutheranism (Weber 2002, p. 83). Therefore, fashion (when not overindulged in) came to be a more desirable option for the purposes of the clergy.

\subsection{The Time of Dispersion}

Upon the death of its key leaders in the 1850s, the körtti movement entered a time of 'dispersion' [hajaannus], associated with increasingly sectarian and marginalising characteristics as well as theological disagreements within the movement (Salomäki 2010). Left, in many ways, outside the Evangelical Lutheran Church of Finland, the movement turned inwards and sought to establish a stricter division between themselves and others. During this time, the körtti dress became more 
fossilised, and its use stricter than before. It was no more a dress that a person donned upon 'awakening', but instead came to be a tool of control, particularly imposed upon small children. Boys were dressed in körtti dress at the age of 4-5, and girls usually at the age of 10 (Mäntykoski 1973). Through the 1860s to 1890 s, the style, details and wearing of körtti dress were strictly socially regulated, and any deviance in detail was considered 'worldliness' and therefore a sin to be condemned.

Vilkuna (1928), drawing upon interviews with elderly members of the movement, writes about this time as one when exact rules defined what the attire should look like. Yet his detailed account reveals that there were actually a number of changes in details, mostly influenced by fashions and the availability of new materials and garments. For example, although the körtti dress was supposed to be made of home-grown, home-woven fabrics, already from the 1880s onwards using shop-bought materials became possible, which also made the garments look different, as the materials were typically thinner, softer and of more even quality (Mäntykoski 1973). Likewise, shop-bought buttons were preferred by young men and came to replace the previously used wooden ones, to the dismay of some elderly members of the movement who considered the buttons too shiny (and thereby too worldly) (Vilkuna 1928). It seems that while it was crucial for the movement's survival to demand a strict use of the körtti dress, it was not possible to defend it against all fashionable changes and pragmatic demands. On the other hand, the körtti dress was shunned and often ridiculed by others, and in practice kept the youth wearing it from entering certain 'worldly' places (Mäntykoski 1973), so despite these changes, it retained its recognisability and thus performed its function as a creator and enforcer of boundaries that operated to keep the sect alive.

\subsection{The Time of Integration and Nationalism}

From the 1890s onwards, the körtti movement, again, went through some important changes. This was a time when Russia sought to tighten its control over autonomous Finland, and when the Finnish intelligentsia increasingly organised to defeat such intentions (Huhta 2007). Eventually, this led to independence from Russia in 1917, by declaration and through the acceptance of the declaration by the post-revolutionary Soviet Russian government. In the years leading up to this, the körtti movement came to be framed externally as embodying a romantic ideal of modest and reliable Finnish peasantry, a strong counter force to socialist and communist workers' movements. The körtti dress played an important part in this, particularly when an annual meeting came to be established from the early 1890s onwards. With time, Herättäjäjuhlat (the Awakening Festival) came to be known in Finnish media partly through nationalistic narratives where a homogenously dressed, collectively organised (instead of individually 'selfish'), religiously-oriented people represented a bright future promise for Finland: they were the 'real' people of Finland to be relied upon in nation-building (Jurva [1917] in Huhta 2007, pp. 211-13). In effect, körtit were seen as a desirable 'traditional' element in a society where the demands of Russia on the one hand, and the urban working class on the other, threatened the stability and position of the local bourgeoise intelligentsia. Ultimately, the romanticising narratives served as an argument against the perceived threat of socialism and communism. By stressing those features that were considered positive, such as reliability, healthiness, collectivity and piety, a form of nationalism and an idea of 'people' were constructed that declared as the 'best' type of folk those who were not challenging class stratification and social order (Huhta 2007). Among those who described the movement in a romantic, nationalist, Fennoman light were journalists working for publications such as Suomen Kuvalehti (1873-1880, 1917-), Päivälehti (1889-1904, later Helsingin Sanomat, 1905-) and Uusi Kuvalehti (1890-1903), as well as other prominent members of the Fennoman intelligentsia, such as the author Juhani Aho (1861-1921, originally Johan Brofeldt—it was very common for Swedish-speaking Finns to translate their names during this time of Fennomania) and the painter Venny Soldan-Brofeldt (1863-1945), whose painting 'Heränneitä' (1898) is one of the best known visual representations of körtti women (Figure 4). 


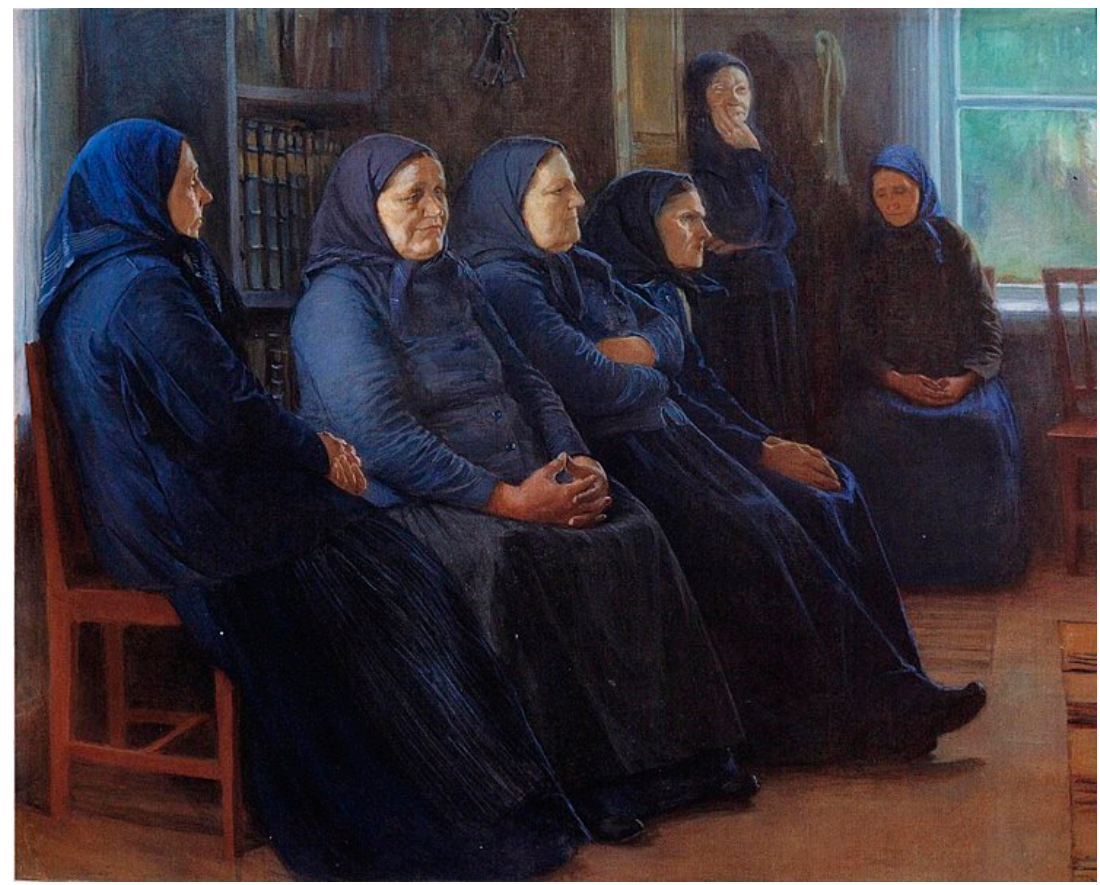

Figure 4. Venny Soldan-Brofeldt (1863-1945): Heränneitä, 1898. Collection: Ateneum (the Finnish National Gallery).

The Awakening festival also gave the members of the movement a chance to meet each other and get a sense of the spread and prominence of the movement. But more importantly, the new movement leaders, most notably Wilhelmi Malmivaara (1854-1922, born Malmberg), believed that the movement would be best placed within the Church rather than as a sect outside of it. The körtti movement became less marginalised, but also more politically involved, albeit in no centralised or generally agreed manner (Huhta 2007). The körtti dress came to symbolise not only belonging to the movement but also characteristics considered desirable by many Fennomans: un-selfishness, piety and modesty. Such characteristics reinforced körtti dress's anti-fashion nature, but also forcefully drew it into the realm of nationalist politics. An elementary part of this kind of framing was the exclusion of ecstatic elements from the movement's religious practice, which typically also led to the exclusion of female leadership that had previously been fairly prominent (Sulkunen 1999). Arguably, this re-enforced the status of the male körtti dress as more profoundly symbolic of the movement than the female dress.

The Russian Revolution shook Finland forcefully in many ways. While it enabled independence, this was very soon followed by a traumatic, bloody civil war in 1918 where the White side feared that a victory for the Reds would lead to becoming part of Soviet Russia and thus annul the young independence. During the war, the körtti dress gained a new kind of reputation. Members of the movement, considering Communism as a threat to religious order, fought on the White side, and one whole regiment wore the körtti dress, kneeling to prayer before fights and singing körtti hymns afterwards (Huhta 2007). These soldiers were associated with the Lapua area of southern Ostrobothnia, which at that time had become a centre for the movement more generally. The Awakened were considered to be brave soldiers, and a sort of myth making made them famous among their own and infamous on the other side, where it was lamented that Christians could be so misled that they would fight for the Whites (Huhta 2007). During the civil war, meanings associated with the male körtti dress came to be increasingly militant. Due to the exclusion of female leadership and an association with militarism, the körtti dress increasingly came to be associated with the male form of it. It is indeed the case that after the war, the female compulsion of wearing the dress as everyday wear reduced faster than the male obligation to do so (Mäntykoski 1973). 
It is along with this more military association that some interesting changes in the male körtti jacket happened. With shop-bought materials, the line of the jacket came to be more tailored-looking and uniform-like (Mäntykoski 1973). Sharp lapels also appeared in the front, whereas previously the very lack of lapels had been a distinctive feature. Previously, the sleeves had had turns, which now started to disappear, further making the jacket differ less from more normative male attire. A hat was increasingly worn instead of a round cap (Vilkuna 1928). Altogether, these changes made the male dress conform increasingly to mainstream fashion trends although it was still understood as 'traditional'.

The slow decline of körtti dress started in the 1920s and 1930s. First, it was permissible to give up the dress for the sake of education. Therefore, those who pursued secondary education often ceased to wear körtti dress at school (Konttinen n.d.). Those who went to study in cities, such as Helsinki, only wore the dress back home. The movement started to spread in Helsinki at the end of the 19th century, and in the 1920s and 1930s was largely formed of university students, who understandably left their peasant dress in order to fit their new (higher-status) position and urban environment (Salomäki 1978). It makes sense that this was allowed by parents: it would have been impossible to control their offspring, and the best the parents could hope for was that they would not gain any worse habits than a worldly dress style. The female körtti dress followed a different kind of pattern, as girls were less likely to go away to study. It was always a custom to demand its wear at a later age than boys', and slowly this expectation loosened such that the körtti dress was expected of girls only in special occasions, such as Church confirmation ceremonies (typically at the age of 15) or school celebrations. Yet it was still undesirable for körtti youth to mix with other youth, and dress was considered one effective way of managing this: it was impossible to go to general youth gatherings wearing the körtti dress (Mäntykoski 1973).

\subsection{The Time of Organisation}

After WWII, the körtti dress increasingly disappeared from rural areas, too. At the same time, the körtti movement became more firmly established within the Church than ever, and the Herättäjä-Yhdistys association was founded right after the war. For male members of the movement in particular, the war had been an experience that unified them with other men, rather than separating them into their own religious group. They had gotten used to their military uniforms and returning to the dress of the time before war seemed difficult. A post-war shortage of textiles also made it difficult to get körtti dresses made for soldiers returning from the front. Therefore, many rural men quietly gave up the attire (Mäntykoski 1973). In a struggle against the disappearance of the female körtti dress during the 1940s and 1950s, certain fashion elements such as making the skirt lighter by using less, and lighter, material and shortening the hem from full-length to mid-calf were introduced, but such compromises did not stop the eventual death of the dress as everyday wear. It was simply considered too inconvenient by young people. The dress style was deemed too uncomfortable, too heavy and too unpragmatic on the one hand, and too socially secluding on the other. While some elderly people were known to wear the dress through to the 1970s, by that time no young person was known to have donned the attire anymore. While the körtti movement within the Church was more organised and institutionalised than before, it was also less visible outside the Church.

\section{5. 'New' or 'Modern' körtti Dress: Liberalisation, Drive for Equality and Subtle Belonging}

The körtti dress today survives as a special-occasion dress. Although some have claimed that it has gone through a level of 'revival' (Eerola n.d.), it is not common in any sense. In the Herättäjäjuhlat annual gathering one can see some people, mostly women, wearing it, but it is recognised that to find a maker of a male körtti dress would be challenging. The Herättäjä-Yhdistys association has patterns for the female dress that can be rented, but male körtti dress patterns have typically died with their makers (Hylkilä 2004). Some old garments, usually inherited from one's grandparents, survive and are worn at Herättäjäjuhlat. 
One element of the dress survives in a slightly more prominent manner: the körtti scarf (körttihuivi). This is the 'chest scarf' (rintahuivi) that used to be worn over the shoulders and across the chest by körtti women. This dark scarf in its most recognisable form had a blue stripe pattern that is still used today in the cotton scarves sold by Herättäjä-Yhdistys (Figure 5). The same visual element is used by the Körtti Museum in its displays (Figure 6). This stripe pattern is considered by many to be one of the most recognisable and traditional signifiers of the movement, and its use has been versatile over the years. For example, a new kind of körtti scarf, a tube scarf, was made for fundraising purposes for the Tampere Herättäjäjuhlat in 2018. The woman behind the idea, Petra Perttula, tells that the fabric for the scarf was produced locally from organic cotton, using a scan of a 'traditional' körtti scarf's pattern. As the required fabric for the tube scarf was a knit, rather than a woven fabric where yarns of both the warp and the weft together form the pattern, scanning was found to be the best way to reproduce the pattern in a new kind of material (Figure 7).



Figure 5. The körtti scarf today. Photograph: author.



Figure 6. An exhibition plate at the Körtti Museum. Photograph: author. 


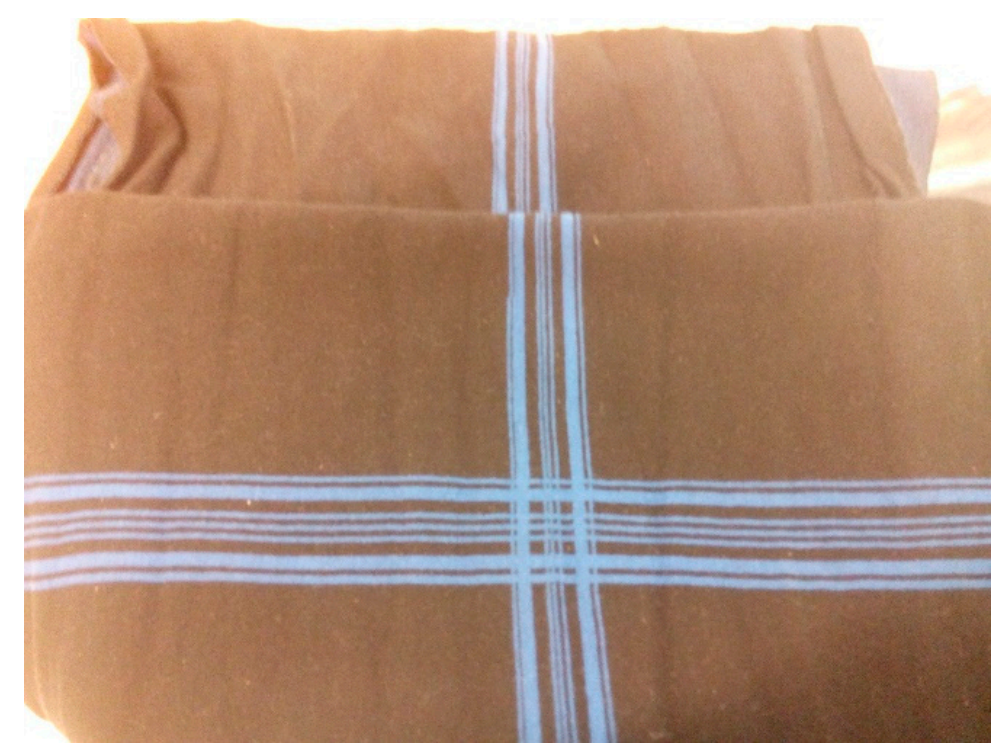

Figure 7. The pattern reproduced in the knit material of a tube scarf. Photograph: author.

\subsection{The Time of Liberalisation}

Although in some ways these new forms of körtti dress are still about community recognisability and belonging, there are elements in the background that need to be given some attention. First, körttiläisyys is a very established movement within the Evangelical Lutheran Church of Finland today. There is no great threat to the movement's survival, and although it is organised under an independent association, it is well integrated within the Church. Second, there has been a significant liberalisation within the movement, initially driven by young left-wing clerics in the 1960s and 1970s, who sought to challenge the movement's right-wing history. Today, the liberalisation is evident in the fact that körttiläisyys is the most liberal of all the revivalist movements that operate within the Church (Salomäki 2010). The liberalisation of the movement in the 1960s and 1970s went together with the idea that the Church should not separate itself from society but should instead act in the world for justice and positive change. This transformation has happened at the same time as the movement has become increasingly urbanised-many today identify as 'urban körtti' (kaupunkikörtti, citykörtti). In terms of values, körtit do not markedly differ from average Finns today (while the members of other revivalist movements are significantly more conservative) (Salomäki 2010). Nor do they usually wish to be distinguished or separated from others, but instead often stress that as the only one that knows answers is God, no one can judge another person's choices or motivations. While it would be impossible to claim that everyone associated with the movement is tolerant and liberal, there is today a significant difference between körttiläisyys and strict sectarian Christianity.

These changes necessarily show in how members of the movement dress and how they seek to communicate their belonging. There are no dress restrictions or requirements today, but there are strategies of communicating belonging. The means of identification seem to have become subtler, especially in everyday life, and the garments used are very mainstream, such as are regularly produced by the fashion industry for secular purposes. An excellent example of this are the t-shirts made for and sold by the youth work section of Herättäjä-Yhdistys, Nuori Yty. Carrying deliberately obscure, typically 3-word verses from Siionin Virret, such as 'murra valta mammonan' (break the power of money), these t-shirts are called by some 'new' or 'modern körtti dress' (Figure 8). For a person outside the movement, the $t$-shirts may not communicate a religious message at all, but for those in the know, 
the message is recognisable. And this is the very point of the $t$-shirts, as I was told by Mika Nuorva of Nuori Yty, who has been active in the t-shirt project since 2005. The t-shirts are black, which suits traditional religious sensibilities of the movement (while also making them look very similar to 'secular' $\mathrm{t}$-shirts), they are mundane, modest and subtle, and while they do not necessarily draw the attention of everyone, they allow for two things: members to recognise each other and to communicate about the movement to others in a fairly discreet manner. An important factor here is that these verses from the hymns are widely recognisable across different revivalist movements within the Church. This is particularly important when a member of the movement wants to take a stance with regard to a political issue that divides the Church, such as gay marriage.

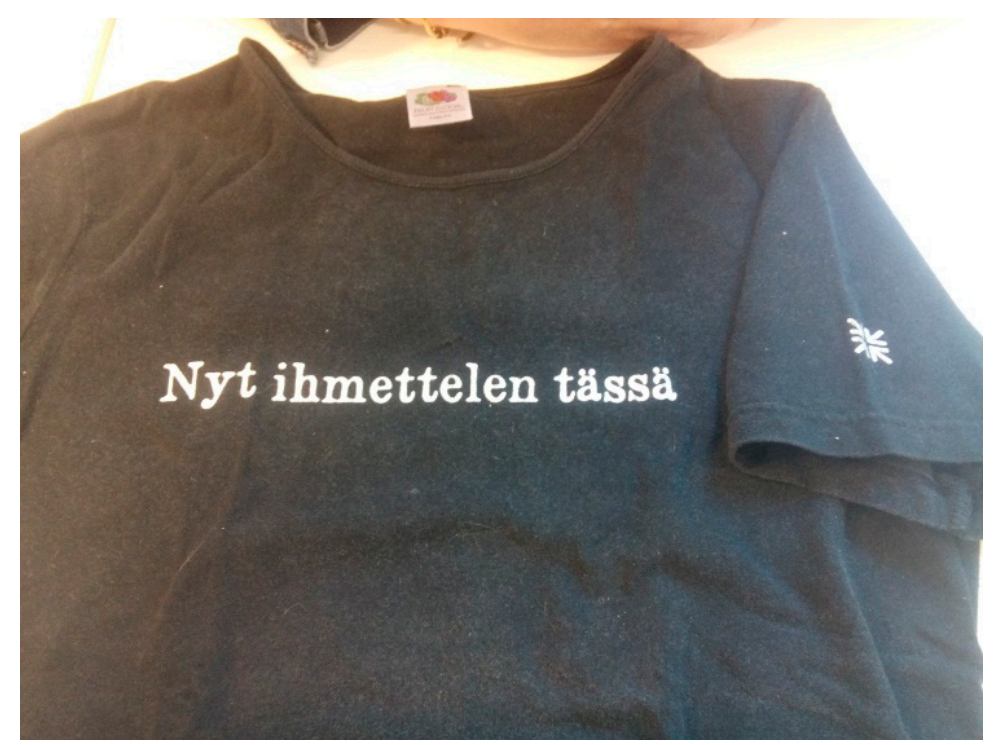

Figure 8. A körtti t-shirt, 'Here I wonder'. The logo of Herättäjä-Yhdistys on the sleeve. Photograph: author.

\subsection{The Time of the Church in Crisis}

The equal marriage law came into force in Finland on 1st March 2017. This placed the Church in a difficult position, as an institution that has the right to perform legally recognised marriage ceremonies. While the Church leadership is divided on the topic, formally the Church forbids its ministers to marry same-sex couples. Yet if a minister performs the ceremony, it is legally binding, while the minister is usually disciplined afterwards (Yle 2017). When the change in law was opposed by several religious movements, Herättäjä-Yhdistys was the one organisation that explicitly stated that they do not oppose equal marriage and equal treatment of people. (Today, a majority of the clergy say they would marry a gay couple if the Church allowed it-Yle 2018.)

In line with this, in summer 2018, Nuori Yty launched a t-shirt in which the hymn citation 'armon valo voittaa' (the light of mercy shall be victorious) is printed in rainbow colours (Figure 9). The multiple messages this t-shirt carries are effective in both creating connections and communicating subtle boundaries. In effect, the shirt communicates both inwards and outwards, telling fellow Church members that the wearer believes the Church should recognise and enact equal marriage, and telling the LBGTQ+ community that there are people inside the Church with positive views on equal marriage (the chosen text reads as explicitly religious, unlike most texts used in these t-shirts). At the same time, the communication of such a stance is subtle (or 'polite', as one of my interviewees put it), which is more in line with general acceptance of a range of opinions and views within the körtti movement. The $t$-shirt is not enforcing a boundary around the movement but rather pointing to existing differences and potentially questioning certain divisions within the Church more generally. 




Figure 9. The 'armon valo voittaa' t-shirt on Instagram. Hashtags include nykyajan \#körttipuku (modern körtti dress), \#pride and \#kirkkokuuluukaikille (the church belongs to everyone). Photograph: courtesy of @amluomi.

So, in many ways, the körtti movement operates between tradition and liberalisation today, using mixed means to communicate its position within the Church. A further means of creating belonging is humour, which both appeals to those who are new to the movement and strengthens the connections between those already within it. It is said that a central liberaliser of the movement in the 1960s and 1970s, Jaakko Elenius (1939-2010), considered humour a positive force:

Humour flashes as a lightening and lifting force. Good [religious] gatherings [seurat] can be said to be fun. Humour is a relative of the Gospel, they together drive Satan away, lighten the heart, and deepen mutual understating between humans. (Herättäjä-Yhdistys, n.p., my translation)

Today, Herättäjä-Yhdistys (n.d., n.p., my translation) in their 'körtti dictionary' defines the role of humour in the movement like this:

$[\mathrm{H}]$ umour, self-irony and a positive outlook on life have a central role in living together. Humour between friends is not only a measure of mutual trust but is also a strengthener of trust.

Another garment illustrates this point: körttipipa. The garment, for which the original idea was by Outi Lehtipuu, and for which the handicraft designer and journalist Hanna Tamminen created the design and made knitting instructions, is a handknitted woollen hat (Figure 10). Designed for the Tampere Herättäjäjuhlat of 2018, it communicates a number of layers of meaning, each of them more or less subtle. The name points to geographical location and local identity. 'Pipa' is a word in Tampere dialect, while other Finns would say 'pipo'. A woollen hat is a traditional garment, and very necessary in the winter in Finland. The hats were handknitted by volunteers, a practice which has a long tradition within the movement. Already in the early 20th century, there were 'sewing gatherings' (ompeluseurat, as opposed to seurat which was and remains a purely religious gathering) in Helsinki, where women (and some men) made products to be sold for the benefit of the movement. Initially, the focus was on poor aid, but the handmade products came to be crucial for the funding of the movement more generally (Salomäki 1978). The practice survives today, albeit being arranged through Facebook groups with members in different parts of Finland, rather than as localised physical gatherings. 


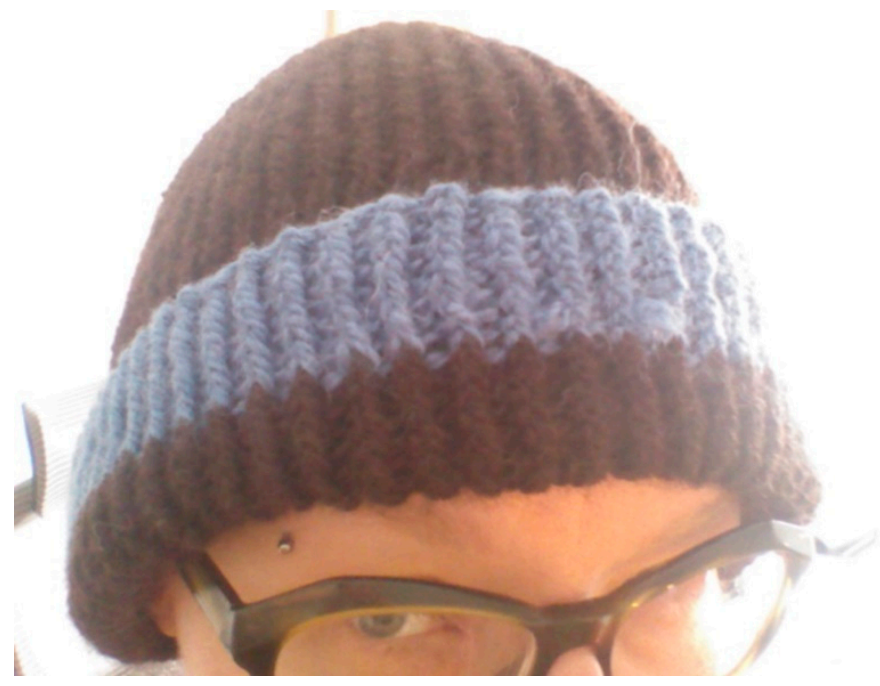

Figure 10. A körttipipa. Photograph: author.

A körttipipa is made of black wool, which again refers to traditional colour and material preferences, with a blue stripe (in many different shades) referring to the blue stripe pattern of the körttihuivi. But a different kind of körttipipa was also available, with a red stripe, and referred to as 'suruton'-sorrowless. This pipa was five euros more expensive than the one with a blue stripe, for worldliness 'should be more costly'. This is an example of the subtleties of körtti humour: mild self-mockery concerning the history of the movement where red was considered unacceptably worldly and sinful and was thereby banned completely. Today's körtti can wear such a garment in spirit of self-irony and humour, as shown in the following discussion concerning the körttipipa in a Facebook forum (my translation).

A: Sorrowlessness and sorrowless people used to be spoken of. It meant those who were not mindful of their sins. [They] didn't care where they'd spend their eternity. They could blithely [literally: without sorrow] commit sin.

B: Such as wear a woollen hat with a red stripe :)



Körttipipa was a great success, and particularly the 'sorrowless' hat proved popular, selling out very quickly, despite the higher price.

\section{Conclusions}

As this historical-sociological exploration of the körtti dress has shown, there have been a number of types of changes involved in the style, meanings and understandings of the attire: political/social/religious on the one hand, and material/fashion/retail-related on the other. Changes have been both driven from within the körtti movement itself and caused by external forces. They have also been more and less spontaneous or intentional in character. Therefore, dress strategies have varied widely throughout the history of the movement. One general theme here is the purpose of symbolic boundaries (or crossing thereof). A strategy of survival, symbolic boundaries often seek to exclude that which is considered harmful and threatening (Douglas 1984). This works particularly effectively when there is both a desire within a group to be separated from others, and a desire from the side of others to exclude them. Through such processes, hard boundaries are constructed. But when there is a desire for more subtle co-existence, symbolic boundaries are constructed in softer, less obvious ways. Yet those boundaries exist. It is through subtle means that a körtti today stresses her or his liberal stance in terms of equal marriage. But this stance may be as central to her or his sense of identification as the traditional körtti dress was for her or his great-great-grandparent. Furthermore, neither of them 
was or is free from the influences of both social and fashion forces. This is why fashion and religion must be interconnected: both are central forces in society, and both speak to each other in a myriad of ways, some more open, others more hidden and subtle.

Fashion's association with the secular and the 'modern' is a long-standing idea within fashion studies (see, e.g., Wilson 1985). Yet, as I have shown here, established religious leaders do not necessarily shun fashion, and may be motivated to reject religious dress instead, when the movement the dress represents is deemed religiously and/or politically undesirable within the established order. Fashion, too, can infiltrate seemingly 'traditional', fossilised dress phenomena. And despite mainstream fashionable and stylistic elements, an attire can become symbolic of (nationalist) political intentions that view it as 'traditional', and thereby its wearers as 'reliable' and 'un-selfish'. Mainstream garments can also be used for religious purposes in a manner that is recognisable to co-religionists but not necessarily to everyone. All these factors indicate that the interplays and interfaces of fashion and religion on the one hand, and 'traditional' and 'modern' on the other, must be subjected to further critical review and analysis. I hope to have encouraged and contributed towards such a fashion studies project in this paper.

Funding: This research received no external funding.

Acknowledgments: I wish to thank the Körtti Museum at Wanha Karhunmäki, and particularly Heikki Keisala for his kind assistance in answering my questions. Thanks are also due to my other informants, some of whom are mentioned in the text above, and others who remain anonymous.

Conflicts of Interest: The author declares no conflict of interest.

\section{References}

Almila, Anna-Mari, and David Inglis. 2017. What is "Fashion" Really? The Promise of an Ecumenical Analytic for Fashion Studies and Beyond in a Globalized World. In Epistemology and Transformation of Knowledge in Global Age. Edited by Zlatan Delić. London: Intech.

Arthur, Linda B., ed. 1999. Religion, Dress and the Body. Oxford: Berg.

Arthur, Linda B., ed. 2000. Undressing Religion: Commitment and Conversion from a Cross-Cultural Perspective. Oxford: Berg.

Aspers, Patrick, and Frederic Godart. 2013. Sociology of Fashion: Order and Change. Annual Review of Sociology 39: 171-92. [CrossRef]

Barker, Eileen. 2001. A comparative exploration of dress and the presentation of self as implicit religion. In Dressed to Impress: Looking the Part. Edited by William J. F. Keenan. Oxford: Berg.

Classen, Pamela E. 2004. The Robes of Womanhood: Dress and Authenticity among African American Methodist Women in the Nineteenth Century. Religion and American Culture 14: 39-82. [CrossRef]

Dillon, Michele, ed. 2003. Handbook of the Sociology of Religion. Cambridge: Cambridge University Press.

Douglas, Mary. 1984. Purity and Danger: An Analysis of the Concepts of Pollution and Taboo. London: Routledge.

Eerola, Eeva. n.d. Körttipuku kansanpukuna. Lapua: Herättäjä-Yhdistys.

Hakulinen, Riikka. 2008. Ei tupsuus taivahasehen mennä: Heränneiden pukeutuminen 1800-luvulla. Master's thesis, University of Helsinki, Helsinki, Finland.

Hawley, Jana M. 2017. The Amish Prayer Cap as a Symbol that Bounds the Community. In The Routledge International Handbook to Veils and Veiling Practices. Edited by Anna-Mari Almila and David Inglis. London: Routledge.

Herättäjä-Yhdistys. 2018. Yhteen hiileen: Herättäjä-Yhdistys ry:n vuoden 2017 vuosikertomus ja tilinpäätös. Lapua: Herättäjä-Yhdistys.

Herättäjä-Yhdistys. n.d. Körttisanakirja. Available online: https://www.h-y.fi/herannaisyys/korttisanakirja.html (accessed on 4 April 2019).

Huhta, Ilkka. 2007. "Täällä on oikea Suomenkansa" Körttiläisyyden julkisuuskuva 1880-1918. Helsinki: Suomen Kirkkohistoriallinen Seura.

Hylkilä, Satu. 2004. Körttipuku. Master's thesis, University of Helsinki, Helsinki, Finland.

Hyme, Lynne. 2013. The Religious Life of Dress: Global Fashion and Faith. London: Bloomsbury.

Jensen, Jeppe Sinding. 2014. What is Religion? London: Routledge.

Konttinen, Penna. n.d. Muistoja ja mietteita. Self-published. 
Kopisto, Sirkka, and Pirkko Sihvo. 1996. Puku Suomessa 1750-1900. Helsinki: Museovirasto.

Lehtinen, Ildikó, and Pirkko Sihvo. 1984. Rahwaan puku. Helsinki: Museovirasto.

Lewis, Reina. 2015. Muslim Fashion: Contemporary Style Cultures. Durham: Duke University Press.

Lindt-Gollin, Gillian. 1967. The religious factor in social change: Max Weber and the Moravian Paradox. Archives de Sociologie des Religions 23: 91-97. [CrossRef]

Mäntykoski, Matti. 1973. Körttipuvun käyttö ja merkitys Nurmossa 1800-luvulta nykypäiviin. Laudatur thesis, University of Helsinki, Helsinki, Finland.

Ribeiro, Aileen. 2003. Dress and Morality. Oxford: Berg.

Salomäki, Mauno. 1978. Herännäisliike Helsingissä 1895-1939. Laudatur thesis, University of Helsinki, Helsinki, Finland.

Salomäki, Hanna. 2010. Herätysliikkeisiin sitoutuminen ja osallistuminen. Helsinki: Kirkon Tutkimuskeskus.

Sulkunen, Irma. 1999. Liisa Eerikintytär ja hurmosliikkeet 1700- ja 1800-luvulla. Helsinki: Gaudeamus.

Tarlo, Emma, and Annelies Moors, eds. 2013. Islamic Fashion and Anti-Fashion: New Perspectives from Europe and North America. London: Bloomsbury.

Vilkuna, Kustaa. 1928. Heränneiden körttipuku. In Etelä-Pohjalaisen Osakunnan julkaisu. Kyrönmaa II. Helsinki: Sana. Weber, Max. 2002. The Protestant Ethic and the Spirit of Capitalism. New Translation and Introduction by Stephen Kalberg. London: Blackwell.

Wilson, Elizabeth. 1985. Adorned in Dreams: Fashion and Modernity. London: Virago.

Yle. 2017. Pastori vihki homoparin-Sai kirjallisen varoituksen. Yleisradio. October 3. Available online: https://yle.fi/uutiset/3-9863764 (accessed on 4 April 2019).

Yle. 2018. Pappien suvaitsevaisuus nousussa: Enemmistö kannattaa homoparien vihkimistä. Yleisradio. October 17. Available online: https://yle.fi/uutiset/3-10462007 (accessed on 4 April 2019).

(C) 2019 by the author. Licensee MDPI, Basel, Switzerland. This article is an open access article distributed under the terms and conditions of the Creative Commons Attribution (CC BY) license (http://creativecommons.org/licenses/by/4.0/). 